\title{
THE CHALLENGES AND ACTUAL QUESTIONS OF THE AGRICULTURE IN YEMEN
}

\author{
Abdulghani Al-sabai ${ }^{1}$, György Iván Neszmélyi ${ }^{2}$ \\ ${ }^{1} \mathrm{PhD}$ student, ${ }^{2}$ associate professor \\ ${ }^{1}$ Szent István University, Faculty of Economics and Social Sciences, Doctoral School of \\ Managemenet and Business Administration, ${ }^{2}$ Budapest Business School - University of \\ Applied Sciences \\ E-mail: sabai68@gmail.com,neszmelyi.gyorgy@uni-bge.hu
}

\begin{abstract}
Agriculture employs more Yemenis than any other sector and spate irrigation is the largest source of irrigation water. Spate irrigation however is growing increasingly difficult to sustain in many areas due to water scarcity and unclear sharing of water amongst users. Mostly due to high population growth, misguided agricultural development and the growth of qat, a lack of law enforcement to regulate water use, and a vulnerable climate to climate change, the crisis may soon reach catastrophic levels. The agriculture uses $93 \%$ of the potable water, and does not actively encourage sustainable water saving techniques. Qat (Catha edulis; recreational drug) cultivation uses $40 \%$ of the potable water. The water crisis could be mitigated by reducing qat production.
\end{abstract}

Keyword: Yemen, sustainable agriculture, agricultural policy, irrigation

JEL Classification: R12, Q18, Q15, N55

LCC: S560-571.5, HD1401-2210

\section{Introduction}

Yemen is a low-income country which has been long ago striving to stabilize its economy, however the ongoing war has blocked Yemen's exports, dropped the currency's exchange rate, accelerated inflation. The food and fuel imports considerably diminished while the infrastructure was damaged. The long-lasting conflict generated a severe humanitarian crisis (CIA World Factbook, 2017) Yemeni population thus need humanitarian assistance in terms of food and healthcare in short term but first and foremost peace.

Agriculture is a key sector in the Yemeni economy, and provides a main source of employment for 54\% of the population. Agriculture produced 17.5\% of Yemen's GDP in 2010 (Source: Central Statistics Organization, Statistic book, 2010), according to the Central Statistics Office of Yemen. Agriculture also plays an important role in food security, (Guth et al. 2000) in improving the trade balance, and in efforts towards integrated rural development. In addition, the agriculture sector helps to stabilize the population by reducing internal migration and its related social and economic problems. The agriculture sector is also key factor in natural resource management, and may consume up to $90 \%$ of available water in Yemen (UN, Yemen Humanitarian Response Plan 2013).

The labour-intensive sector is largely underdeveloped and inefficient, as a result of soil erosion, the high cost of credit and land, a lack of investment, and the scarcity of water. Most of the cultivated land is irrigated and dependent on groundwater, but high demand could exhaust water 
supplies by 2020. Although agricultural output has increased steadily in the past few years, crop yields remain low relative to those produced by comparable countries.

Major agricultural products include fruits, vegetables, and cereals, but production is rarely sufficient to meet domestic demand. As a result, Yemen continues to import most of its food. Yemen also cultivates qat, a mildly narcotic_plant indigenous to Africa. Although legal, the government has recently moved to ban its consumption in public offices and on army_duty due to economic and social costs associated with those under the influence. It continues to be widely consumed, and future efforts to ban it are unlikely. The Gross Domestic Product (GDP) in Yemen was worth 18.21 billion US dollars in 2016. The GDP value of Yemen represents 0.03 percent of the world economy. GDP in Yemen averaged 17.01 USD Billion from 1990 until 2016, reaching an all-time-high of 43.23 USD Billion in 2014 and a record low of 4.17 USD Billion in 1994.

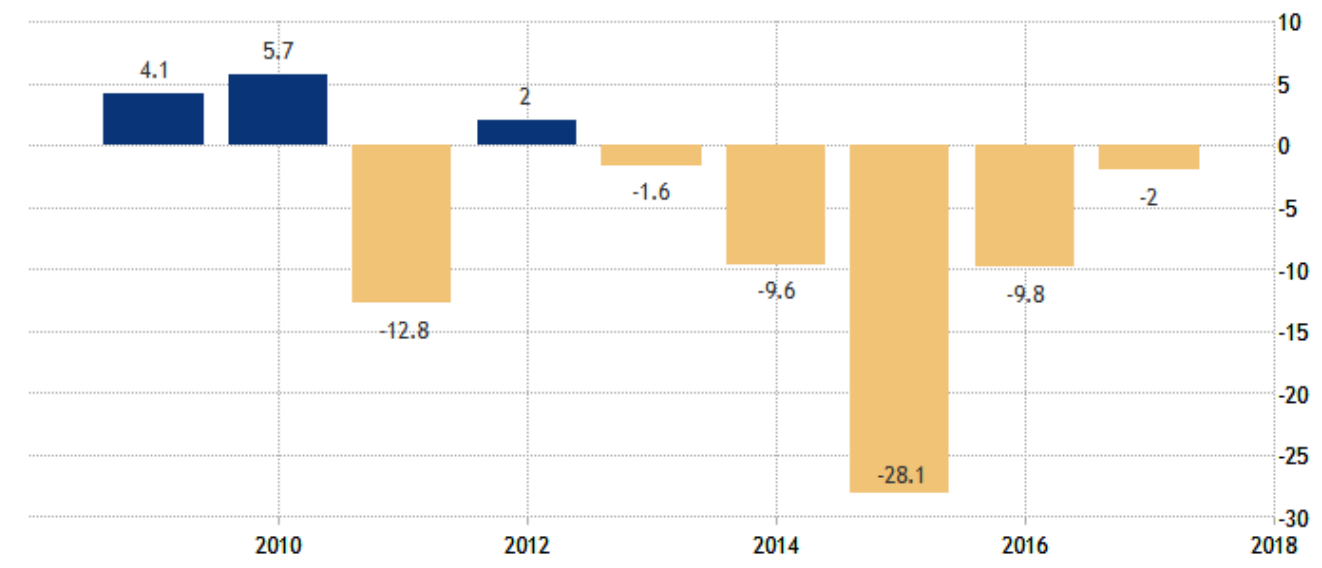

Figure 1: Real GDP growth in Yemen, 2009-2017 (\%)

Source: Trading Economics on the basis of Central Statistics Office of Yemen (2018)

\section{The objectives of the research}

Yemen has a long history of developing strategies in the agriculture sector, This study seeks to examine the effect of agricultural production on Yemen's economic growth, because agriculture accounts for $61.2 \%$ of GDP. About $11 \%$ of Yemen's population lives in rural areas. Estimated direct employment in the agriculture sector by $33.6 \%$ of the labour force. In addition, the agricultural sector contributes to the employment rate of the labour force in the areas of transport, processing and trade, which would increase the employment of the sector to $21 \%$ thus, the agricultural sector is considered to be the most important sector in the field of development in Yemen because of its role in creating job opportunities rural areas, supporting the economy in agricultural communities, and providing food security where its contribution to GDP at the national level (CIA, The World Factbook, 2017).

\section{Material and Methods}

The data were collected from primary and secondary sources, these include the Statistics Office of Yemen, The World Factbook of CIA and Trading Economics website) has been studied in relation to the land area and agriculture production. Also, interview conducted among the Yemenis, intellectuals, information from the journals and internet. It was concluded from the data that Yemeni farmers have great hope for the importance of agriculture to the country. 
In the first step of the study, the existing data has been standardized. Thereafter, the findings as shown in Taiz city, where qat and coffee are produced in several quarters and my observation in several fields, examined how mathematically can be organized into production groups. By standardization, we have eliminated the size differences between country's states. In the research course, testing methods were supplemented by deep interviews along with secondary research. Mention has to be made about the fact that since the early 2010's Yemen has been seriously hit by the civil war including the intervention of Saudi Arabia therefore data collection, especially regarding the recent years was very difficult, in some cases hardly possible. Therefore, in some cases we needed to use international databases in our research which are also merely rather estimates than reflecting exact real figures.

\section{The importance and challenges in the Agriculture Sector of Yemen}

Agricultural sector has a predominant role in Yemen, its contribution to GDP was $24.1 \%$ in 2017 (CIA World Factbook), while agriculture employs more than 54\% of the labor force and connected to about $73.5 \%$ of the population. The major crops and products are grain, fruits, vegetables, pulses, qat, coffee, cotton; dairy products, livestock (sheep, goats, cattle, camels), poultry; fish (CIA World Factbook, 2017).

Mention has to be made of the fact that Yemen lacks good quality arable land, the majority of the surface area of the country is unusable or degraded, only less than one million ha $(2.05 \%$ of the country) can be considered stable land (see in Table 1 and 2).

Table 1: Types and areas of degraded, decertified and stable land in Yemen

\begin{tabular}{|c|l|c|c|}
\hline No. & \multicolumn{1}{|c|}{ Data (classification) } & Area (ha) & \% \\
\hline 1 & Unusable land & $38,917,985$ & 85.44 \\
\hline 2 & Degradation due to water drifts & $5,070,608$ & 11.13 \\
\hline 3 & Degradation by land erosion & 578,189 & 1.27 \\
\hline 4 & Chemical degradation (salinization) & 37,089 & 0.08 \\
\hline 5 & Physical degradation (hardening of the crust) & 12,717 & 0.05 \\
\hline 6 & Stable territory & 933,658 & 2.05 \\
\hline & Total area & $\mathbf{4 5 , 5 5 0 , 2 4 6}$ & $\mathbf{1 0 0}$ \\
\hline
\end{tabular}

Source: Agriculture policies and strategies for Ministry of Agriculture and Irrigation, 2012.

Table 2: The division of the territory of Yemen according to the type of cultivation

\begin{tabular}{|c|l|c|c|}
\hline No. & \multicolumn{1}{|c|}{ Data (classification) } & Area (MHA) & \% \\
\hline 1 & Rocky desert lands and attended & 21.0 & 45.16 \\
\hline 2 & Pastoral lands & 22.6 & 48.60 \\
\hline 3 & Forest and forest lands & 1.5 & 3.23 \\
\hline 4 & Lands under investment & 1.4 & 3.01 \\
\hline & Total area & $\mathbf{4 6 . 5}$ & $\mathbf{1 0 0}$ \\
\hline
\end{tabular}

Source: Agriculture policies and strategies for Ministry of Agriculture and Irrigation, 2012.

Table 3: The cultivated area by irrigation methods in 2015

\begin{tabular}{|c|l|c|c|}
\hline No. & \multicolumn{1}{|c|}{ Data (classification) } & Area (ha) & \% \\
\hline 1 & Land dependent on rain & 468,873 & 40 \\
\hline 2 & Land Dependent on Groundwater & 521,622 & 44.5 \\
\hline 3 & Lands dependent on flood waters & 152,385 & 13 \\
\hline
\end{tabular}




\begin{tabular}{|c|l|c|c|}
\hline 4 & Lands dependent on the water of Ghoul & 29,305 & 2.5 \\
\hline & Total & $\mathbf{1 , 1 7 2 , 1 8 5}$ & $\mathbf{1 0 0}$ \\
\hline
\end{tabular}

Source: Agriculture policies and strategies for Ministry of Agriculture and Irrigation, 2012

So far it is visible that Yemen's natural circumstances are not really favourable for agricultural production. Besides the geographic endowments the lack or scantiness of rainfall can also be pointed out. Figure 2 shows the annual average rainfall in Yemen.

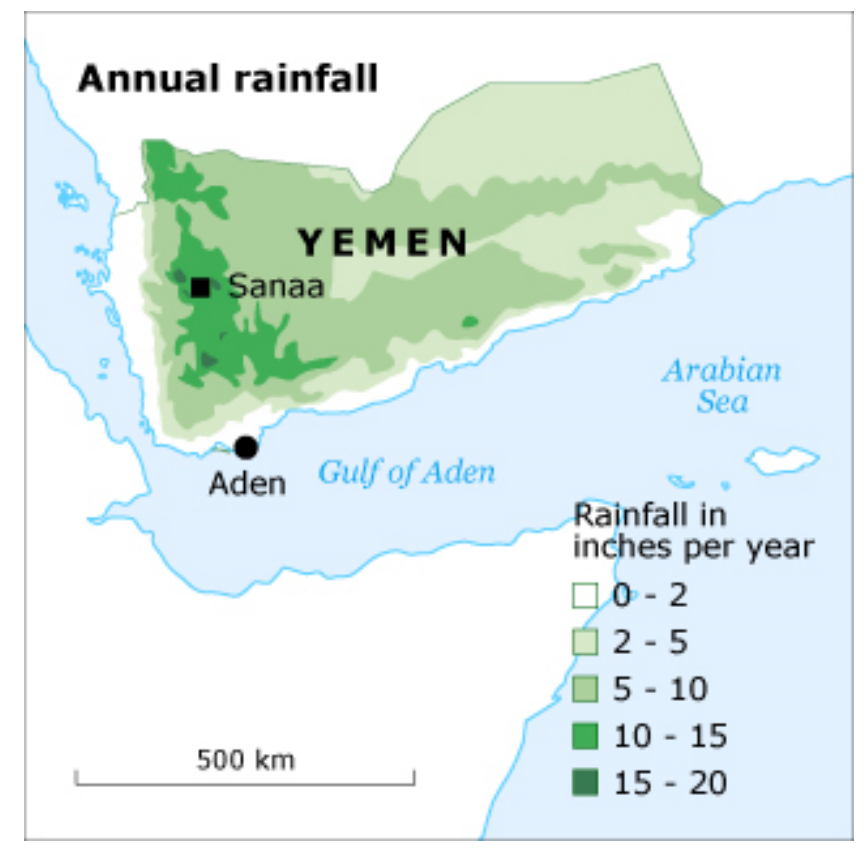

Figure 2: The annual average rainfall in Yemen

Source: Fanack, 2016

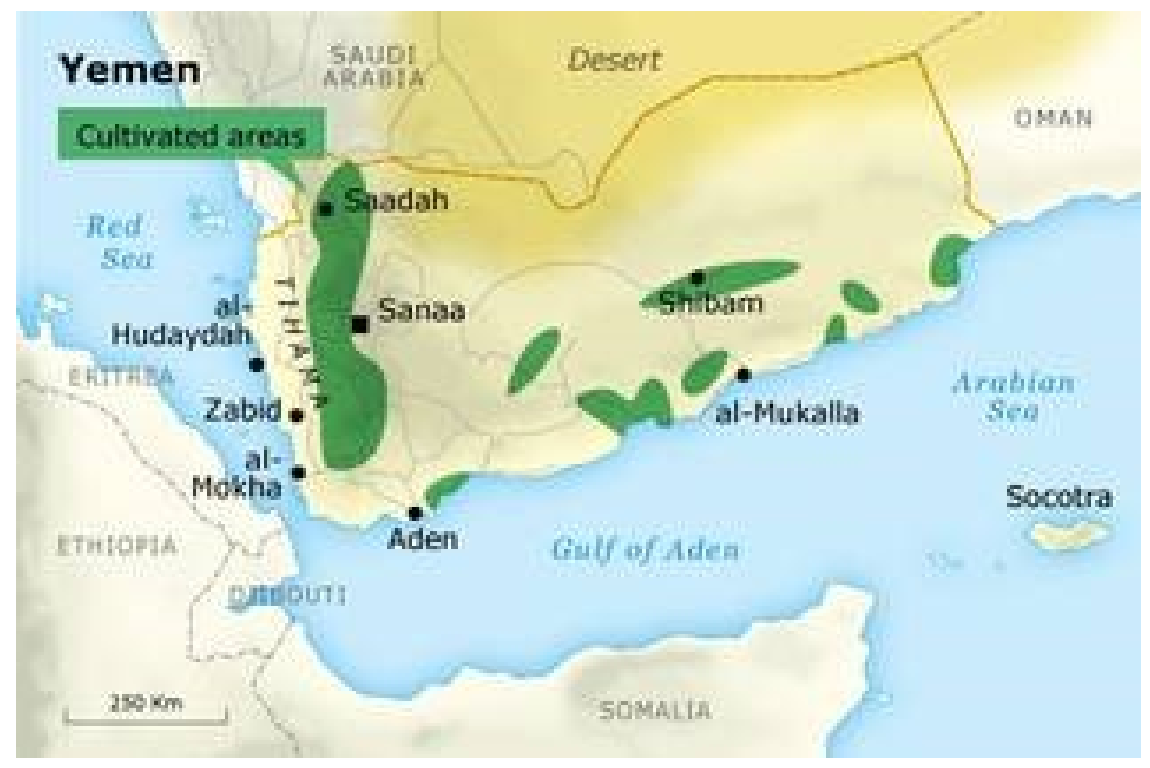

Figure 3: Agricultural regions of Yemen

Source: Fanack, 2016

The challenges in the Yemeni agriculture sector 
Besides the unstable political situation and the devastations of the long-lasting civil war there are still a number of critical issues that the Yemeni agriculture has to face. The most prominent and serious ones are as follows.

\section{Limited Water Resources}

Availability of water is the most often mentioned constraint to the development of the agriculture sector in all parts of Yemen. Yemen relies on two main sources of water: rainwater and groundwater, where Yemen is one of the countries with water scarcity and classified within the arid and semi-arid areas. The average annual rainfall ranging between $200-800 \mathrm{~mm}$, while the rainfall in the three governorates of Ibb, Al-Mahweet and Hajjah is about $1200 \mathrm{~mm}$. Amount of rainfall in all parts of the country ranging between 67.11 billion MC and 93 billion MC per year. Statistics show that the total cultivated land in Yemen in 1970 was about 1.29 million hectares, of which about 37,000 ha were irrigated with groundwater, 120,000 hectares by floods, while about 73,000 hectares were irrigated by springs and water streams and the rainfed area reached 1.06 million hectares. In 2010, the total cultivated area has marginally increased to 1.37 million ha, with increase in groundwater irrigated area to 420.000 ha (almost 11 times), floods irrigated area also increased to 136.335 ha, while the rainfed cultivated area decreased to 695,388 hectares (Al-Eshlah et al. 2011)

\section{Land Resources Impact on Agriculture}

Land is a limited resource in Yemen. The total area of Yemen is 45.55 million hectares, with an estimated area of arable land of 1.61 million hectares, while the cultivated area in 2009 amounted to 1.31 million hectares, of which 695 thousand hectares of rain-fed farms, and an area of irrigated land of 693 thousand hectares. The estimated area of bush and forest land 1.5 million hectares while the total area of grazing land 22.6 million hectares, (Statistical Yearbook, 2010). Mountain agricultural is an amazing sight in Yemen, with terraced agriculture going back hundreds, if not thousands of years. However, the population density is very high in these areas, and every square centimetre is farmed. In this environment, agriculture can only increase through improvements in productivity, and a challenge for the future is posed by inheritance rules that will see small plots divided amongst large groups of siblings. In the coastal and plains areas, land is also limited due to water resources, and high populations. The key result of limited land is the need to focus on productivity improvements to reach agricultural goals. Land resources also need to have better registration and legislative procedures to ensure that conflicts over limited land are minimized, and to ensure that appropriate activities are undertaken on the land that will preserve it as a resource. Land degradation and desertification are also significant issues that need both study and policies to prevent land from being taken out of cultivation.

\section{Increasing Qat Production}

Qat production is increasing in Yemen. It is displacing food crops, and also utilizing limited groundwater. Qat cultivated area estimated at 154,000 ha in 2009 this represents about $22.3 \%$ of irrigated area (Statistical Yearbook, 2010). and qat production consume 30\% of agriculture water uses, while qat mainly cultivated in the highland where water scarcity is critical. Qat consumption is also considered to have a negative impact on society as whole, as lower income families spend too high a percentage of their financial resources on qat consumption. There are also health concerns from chewing qat. However, it is also a significant source of income for farmers, and accounts for a large percentage of agriculture production in Yemen. 
It should be noted that many attempts to address the qat issue have come up with simplistic solutions that do not fully take into consideration rural incomes. The role of the agriculture strategy is to only take into consideration the needs of the farmer and the environment, and to defend this role in the preparation of a national qat strategy.

\section{Marketing Deficiencies}

Marketing of agricultural products in Yemen has many challenges at all levels. Small scale farmers have little access to extension that will provide them with advice on markets for their products, and an effective Market Information System (MIS) is not operating in Yemen. Small farmers are also disadvantaged by limited marketing opportunities provided by traditional retail and wholesale markets, and the lack of associations and organization, inefficiency of markets for agricultural products.

\section{Absence of effective government role and lack of funding}

Throughout the assessment process of agriculture in Yemen, it became clear that there is limited support coming from the government of Yemen to Yemeni farmers. The reason is always the same, with budgets cut to the point where much of the Ministry of Agriculture and Irrigation (MAI), and the governorate offices, cannot function. However, there is a sizeable Agriculture and Fisheries Program Promotion Fund (AFPPF), which goes to subsidize inputs for cooperatives and farmers. Gaps in the financing can be considered as one of the major constraints in the way of agricultural development as it is really difficult to compensate the lack of capital, to develop the innovation in their agricultural activities and to purchase inputs (Széles et al., 2014).

\section{Climate Change}

The possible impacts of the global climate change can hit Yemen very seriously. The Handbook on Yemen Land Ownership and Agricultural Laws expressed the future scenario in 2013 as follows: "Climate change is a critical issue and the impact on water and agriculture has been well documented in a report from 2009 from the World Bank entitled Climate Change Impact Assessment on the Agriculture and Water Sectors, Republic of Yemen. The report indicates a change in rainfall in the year 2100 in Yemen could vary from a reduction of 46 percent to an increase of 45 percent over current levels. However, the report also is very concerned about the over extraction of ground water resources, and predicts a rapid collapse within 15 years. Scenarios for long term climate change are dependent on the over extraction of ground water to be solved by regulation in the near term. The report recommends that water saving strategies should be implemented immediately to protect the ground water, and to protect against a scenario that could see a reduction of rainfall. Yemen to provide a longer time series of date for future climate change modelling activities, and continue to work on strategies that utilize less groundwater to take into account the current over use of water resources. " (Yemen Land Ownership and Agricultural Laws Handbook, 2013: 79).

\section{The main characteristics of the agricultural crop production in Yemen}

Agricultural land (\% of land area) in Yemen was $44.6 \%$ in 2014, according to the World Bank data collection of development indicators, compiled from officially recognized sources. The cultivbated areas (ha) and the amount of production of agricultural crop in Yemen 2011- 2015 were summarized by the Ministry of Agriculture and Irrigation of Yemen (see table 4). 
From economic point of view Yemeni agriculture could significantly increase the production one of the most important export items, the coffee, generating more income or revenue to government purse and having a major impact on the gross domestic product. The coffee sector was one of the pillars of the economy. For example, around 1720 the country recorded highest production of Arabic coffee after the establishment of a Dutch coffee factory in the Mukha region in 1708. In this context, the Yemen Bank for Reconstructions and Development has continued to lend support to the farmers and governments in the region as they consolidate their economies (Káposzta - Tóth - Singh, 2008) on the basis on increased efficiencies and competitiveness in coffee production. Furthermore, the Bank has attached high priority to reducing poverty and decreasing economic and social inequality in the country via provision of loan with less interest rate on lending.

The intellectuals and educated elite in Yemen have played a vital important role on encouraging the local farmers to boost the coffee production and discouraged the Qat production. Therefore, the Government must come up with policies that will replace or support the Qat cultivation area with agriculture farms, subsidized the agricultural farming tools. It should create and expand local and foreign market for agricultural produce. There should be adequate water supply and provide more fund to agricultural sector.

Table 4: The main crops and products of Yemen (ha; $t)$

\begin{tabular}{|c|c|c|c|c|c|c|}
\hline \multicolumn{2}{|c|}{ Crop /Year } & $\mathbf{2 0 1 1}$ & $\mathbf{2 0 1 2}$ & $\mathbf{2 0 1 3}$ & $\mathbf{2 0 1 4}$ & $\mathbf{2 0 1 5}$ \\
\hline \multirow{2}{*}{ Cereals } & Area & 784,844 & 854,689 & 857,024 & 727,069 & 585,658 \\
\cline { 2 - 7 } & Prod. & 816,548 & 909,741 & 863,934 & 699,962 & 459,246 \\
\hline \multirow{2}{*}{ Vegetables } & Area & 80,795 & 89,773 & 87,138 & 81,911 & 69,616 \\
\cline { 2 - 7 } & Prod. & 988,463 & $1,132,852$ & $1,032,414$ & 968,323 & 902,852 \\
\hline \multirow{2}{*}{ Fruits } & Area & 93,989 & 94,123 & 94,380 & 93,968 & 91,447 \\
\cline { 2 - 7 } & Prod. & 991,091 & $1,001,411$ & 999,256 & 993,643 & 938,523 \\
\hline \multirow{2}{*}{ Legumes } & Area & 45,684 & 47,966 & 48,011 & 45,422 & 40,889 \\
\cline { 2 - 7 } & Prod. & 89,820 & 96,013 & 96,765 & 92,216 & 75,988 \\
\hline \multirow{2}{*}{ Qat } & Area & 88,785 & 88,194 & 85,692 & 84,152 & 80,288 \\
\cline { 2 - 7 } & Prod. & 87,911 & 90,199 & 87,960 & 85,538 & 77,017 \\
\cline { 2 - 7 } & Area & 162,584 & 167,682 & 168,772 & 169,386 & 166,557 \\
\hline \multirow{2}{*}{ Teeders } & Prod. & 180,630 & 190,856 & 193,394 & 193,940 & 184,749 \\
\cline { 2 - 7 } & Area & 155,248 & 158,546 & 158,387 & 149,652 & 137,730 \\
\hline & Prod. & $1,970,546$ & $1,954,710$ & $1,933,474$ & $1,778,411$ & $1,533,546$ \\
\cline { 2 - 7 } & Area & $1,411,929$ & $1,500,973$ & $1,499,404$ & $1,351,560$ & $1,172,185$ \\
\hline
\end{tabular}

Source: Ministry of Agriculture and Irrigation of Yemen

\section{Conclusion}

The agricultural sector which is already heavily constrained by structural challenges, such as dwindling water resources, has been further inflicted by the conflict due to substantial increase in prices of agricultural inputs and fuel, transportation costs, as well as increasingly restricted access to markets due to insecurity and reduced overall demand due to the diminishing purchasing power. The crop, livestock and fishery production are severely affected particularly in those governorates with continued insecurity, reduced access to land, agriculture inputs, and disruption of market systems. Cereal production in the country has reduced by $33 \%$ while small ruminants' livestock production has reduced by $40 \%$ for sheep and $42 \%$ for goats in 2016 as 
compared to pre-crisis. Agricultural production is constrained by lack of agricultural inputs $(83 \%)$, lack of animal feed (62\%), crop and livestock diseases $(54 \%)$, and lack or shortage of rainfall $(34 \%)$.

After all Yemen, which is struggling with civil war and poverty faces serious difficulties to provide her population with food in sufficient quantity and quality. It highlights the need to facilitate adequate dietary intake for women and children to promote optimal growth and prevent malnutrition through adequate food provision and livelihood support to families. In short or even mid-term humanitarian assistance is badly needed, however the agricultural potential may be developed in longer run to a level at which Yemen could even be exporter of several crops One idea is to increase the production of coffee which can be relatively easily sold abroad while production of other crops, like qat could be shrunken.

\section{References}

1. Agriculture policies and strategies for the Republic of Yemen

2. Ministry of Agriculture and Irrigation, 7/2009.

3. Agriculture Sector Strategy Matrix 2006-2010 and Plan of Work to Implement Strategy for Two Years 2006-2007, Ministry of Agriculture and Irrigation of Yemen, $10 / 5 / 2006$.

4. Alum's social enterprise, Gold Mountain Coffee Growers, connects Nicaraguan producers to speciality roasters; The Source; October 7, 2014. Available at: https://global.wustl.edu/alums-social-enterprise-gold-mountain-coffee-growersconnects-nicaraguan-producers-speciality-roasters/ [Accessed on: 18-10- 2018]

5. Al-Eshlah, A. - Al-Rubaidi, H. - Al-Sabri, A. (2011): Agriculture's contribution to solving the water crisis National Conference for the Management and Development of Water Resources in Yemen organized by the Ministry of Agriculture and Irrigation in January, 2011 http://www.yemenwater.org/wp-content/uploads/2013/03/Paper-2B.pdf [Accessed on: 18-10- 2018]

6. CIA The World Factbook, Yemen (2017) Available at: https://www.cia.gov/library/publications/the-world-factbook/geos/ym.html [Accessed on: 18-10-2018]

7. Coping Strategies in Rural Yemen and Policy Implications, World Bank Report No. 51027-YE, 10/6/2010.

8. Fanack (2016) website - Available at: https://fanack.com/yemen/geography/ [Accessed on: 18-10- 2018]

9. Framework for FAO's Medium-Term Plan for the Development of Food and Agriculture Sector of the Republic of Yemen 2011-2015, Food and Agriculture Organization of the United Nations, 12/2010.

10. Guth, László ; Káposzta, József ; Kapronczai, István ; Lehota, József ; Molnár, József ; Péter, Balázs ; Puskás, János ; Szénay, László ; Tóth, Tamás ; Villányi, László ; et al. Agrárgazdaságtan Budapest, Magyarország : Mezőgazdasági Szaktudás Kiadó (2000), 242 p.

11. Káposzta, J ; Tóth, T ; Singh, M K 2008. Perspectives on regional economic developement policy and strategy In: C, Can Aktan; Ozkan, Dalbay (szerk.) Management and Behaviour in Organizations. Volume 2 : Selected Proceedings of the First International Conference on Social Sciences Izmir, Yasar University, Paper: 5 , $9 \mathrm{p}$.

12. National Food Security Strategy: Summary, Ministry of Planning and International Cooperation/International Food Policy Research Institute, 11/2010. 
13. National Information Center of Yemen Available at: http://www.yemennic.info $\backslash$ [Accessed on: 18-10- 2018]

14. National Statistical Center, Yemen 2016

15. Qat Production in Yemen: Water Use, Competitiveness and Possible Policy Options for Change; Ministry of Agriculture and Irrigation /FAO, 9/2008.

16. Republic of Yemen Agricultural Strategy Note, World Bank, 28 May 1999.

17. Statistical Yearbook, Central Statistics Office of Yemen (2010)

18. Tradings Economic, Yemen https://tradingeconomics.com/yemen/gdp-growth-annual [Accessed on: 18-10-2018]

19. Széles Zs. - Zéman, Z. - Zsarnóczai, J. S. (2014): The developing trends of Hungarian agricultural loans in the term of 1995 and 2012. Agric. Econ. - Czech, 60, 2014 (7): 323-331. Available at: https://www.agriculturejournals.cz/publicFiles/187_2013AGRICECON.pdf [Accessed on: 18-10- 2018]

20. Yemen Humanitarian Response Plan 2013 (UN)

21. https://ops.unocha.org/Reports/daily/CAPProjectSheet_993_54847_2019112.pdf [Accessed on: 18-10- 2018]

22. Yemen - Land Ownership and Agricultural Laws Handbook Volume 1 Strategic Information and Regulations. International Business Publications, USA, 2013, ISBN: 1-4783-6027-2 [Accessed on: 18-10-2018] 